\title{
Sytuacja dydaktyczna z perspektywy kompetencji komunikacyjnych nauczycieli akademickich
}

KEYWORDS

rationality, communication skills, communication

\begin{abstract}
Jakubczak-Chodźko Magdalena, Sytuacja dydaktyczna z perspektywy kompetencji komunikacyjnych nauczycieli akademickich [The didactic situation from the perspective of academic teacher communication skills]. Kultura Społeczeństwo - Edukacja nr 2(14) 2018, Poznań 2018, pp. 111-117, Adam Mickiewicz University Press. ISSN 2300-0422. DOI 10.14746/kse.2018.14.9.

This article shows a mode of perception of the relevant didactic situation from the perspective of teacher-held communication skills. Using the analysis of rationality, presented are new areas of perception of teacher competence. In addition, with the aid of the approach presented by Jürgen Habermas, it was possible to analyse the significance of communication skills as key in the teaching profession.
\end{abstract}

Sytuacją nazywamy ogół tego, co istnieje lub dzieje się w jakimś miejscu i czasie (Bańko, 2006: 718). Zdaniem Tadeusza Tomaszewskiego sytuacja to „układ wzajemnych stosunków człowieka $\mathrm{z}$ innymi elementami jego środowiska w określonym momencie czasu" (Tomaszewski, 1976: 17). W literaturze pedagogicznej występuje wiele ujęć definicyjnych sytuacji edukacyjnej, która często utożsamiana bywa $z$ sytuacją dydaktyczną. Nie są to jednak terminy tożsame. Za sytuację edukacyjną możemy przyjąć sytuację dydaktyczną i wychowawczą zorganizowaną celowo (Poplucz, 1984: 52). Na potrzeby powyższego tematu skupię się jedynie na sytuacji dydaktycznej, rozumianej jako współdziałanie nauczyciela, uczniów, treści kształcenia, wyposażenia dydaktycznego, a także organizacji kształcenia 
(por. Niemierko, 2007). Jak twierdzi Bolesław Hydzik (1993), termin sytuacja dydaktyczna jest trudny do zdefiniowania. Wynika to między innymi z faktu, że istnieją wątpliwości dotyczące terminologii obejmującej istotę procesu nauczania i uczenia się. W celu określenia sytuacji edukacyjnej w całej jej złożoności Maria Przetacznikowa i Ziemowit Włodarski (1979) używają terminu sytuacja nauczania, Stefan Kunowski (1981) sytuacja pedagogiczna, Wincenty Okoń (1984), Bolesław Niemierko (2007) sytuacja dydaktyczna, Dorota Klus-Stańska (2018) proces dydaktyczny. Można zauważyć, że większość z wymienionych terminów naukowych powstała stosunkowo dawno. Może to oznaczać, że opisywany termin zmienia się, jest inaczej definiowany wraz ze zmianami zachodzącymi w samej „sytuacji dydaktycznej”, w środowisku społecznym, a co za tym idzie, edukacyjnym. Sytuacja dydaktyczna w środowisku akademickim różni się znacząco od sytuacji dydaktycznej w środowisku szkolnym między innymi, natężeniem współdziałania nauczycieli akademickich i studentów, a co za tym idzie, większą swobodą operowania treściami kształcenia (przez wykładowcę), jak również organizacją kształcenia.

Sytuacje edukacyjne można podzielić za Krystyną Kuligowską (1984) na pięć głównych rodzajów wyodrębnionych ze względu na funkcje, jakie spełniają: odtwórcze, zapamiętywania, umiejętnościowe, twórcze, wartościowania. Proces kształcenia w szkole wyższej składa się z następujących elementów, zwanych elementami strukturalnymi lub elementami stałymi w teorii i praktyce dydaktycznej (por. S. Palka, 2011: 21-22): cele oparte na bazie aksjologicznej, treści kształcenia i samokształcenia, metody/strategie/techniki, formy organizacyjne, środki dydaktyczne, zasady kształcenia i samokształcenia, a także kontrola i ocena przebiegu efektów procesu kształcenia i samokształcenia. Ponadto można wyróżnić czynniki warunkujące przebieg i efekty procesu dydaktycznego, w skład których wchodzą czynniki związane z cechami psychofizycznymi studentów, czynniki związane z cechami psychofizycznymi nauczyciela, czynniki związane z cechami środowiska lokalnego, szkolnego i rówieśniczego. Ostatnim z elementów strukturalnych procesu kształcenia są podmioty procesu dydaktycznego, do których należą sposoby komunikacji i współdziałania dydaktycznego (Sajdak, 2013: 457-459). Wobec powyższego pełna sytuacja dydaktyczna wymaga współwystępowania wszystkich czynników, w skład których wchodzi również sposób motywowania uczniów przez nauczyciela. Skuteczność motywacji zależy od rodzaju i formy komunikatu skierowanego do adresata. Wobec czego, koniecznym warunkiem wydaje się posiadanie kompetencji komunikacyjnych przez nauczycieli, nauczycieli akademickich, którzy inicjują sytuacje edukacyjne. Interesujący wydaje się sposób organizacji procesu kształcenia pod wpływem rodzaju posia- 
danych kompetencji komunikacyjnych nauczycieli akademickich. W tym celu przeprowadzę analizę racjonalności, która jest pierwotną $\mathrm{w}$ inicjowaniu procesu kształcenia i zaistnieniu aktu komunikacji.

W poniższym artykule zostały uwzględnione podejścia prezentowane przez Jürgena Habermasa i zainspirowanego jego myślą Roberta Kwaśnicę, dotyczące genezy racjonalności emancypacyjnej jako nadrzędnej nad racjonalnością adaptacyjną (Racjonalność adaptacyjna w pedagogice - coraz częściej odrzucana przez nauczycieli, jako metoda wywierania wpływu na wychowanka, behawioryzm, formowanie ludzi według z góry ustalonych wzorów), w obrębie której ustala się wiedza praktyczno-moralna. Termin „racjonalność” rozumiany jest tu za R. Kwaśnicą jako „głęboka struktura ludzkiego doświadczenia, wyznaczająca strukturalne ramy, w obrębie których interpretujemy świat i własne istnienie" (Kwaśnica, 2007: 10). Istnieją pewne warunki niezbędne do kształtowania się racjonalności. Należą do nich: język, działanie, społeczeństwo, kultura i jednostka. Racjonalność stanowią zarówno działania instrumentalne, jak i komunikacyjne. W pierwszym i drugim działaniu doświadczamy świat za pośrednictwem języka, ale za każdym razem inaczej go usensowniamy, przez co kształtuje się odmienny typ doświadczenia, odmienna struktura, a co za tym idzie, odmienna racjonalność. Oznacza to, że racjonalność sama zmienia się pod wpływem doświadczeń. Przytoczona definicja racjonalności R. Kwaśnicy w pełni wpisuje się w definicję dydaktyki sformułowaną przez D. Klus-Stańską: „Dydaktyka zajmuje się uczeniem się, które przebiega wówczas, gdy celowo je wywołujemy w zorganizowany społecznie sposób. Jeszcze dokładniej można powiedzieć, że przedmiotem analiz dydaktyki jest intencjonalne tworzenie warunków do uczenia się" (Klus-Stańska, 2018: 21). Na intencjonalności tworzonych przez nauczyciela warunków i sposobów, w jakich odbywa się nauczanie i uczenie, opiera się preferowany/ dominujący rodzaj racjonalności. Celowość działań nauczyciela zakłada z góry przyjętą drogę do osiągnięcia konkretnych, zamierzonych efektów kształcenia. Wiąże się to z jednym z dwóch typów racjonalności, za którymi opowiada się (świadomie lub nie do końca świadomie) nauczyciel. Z badań prowadzonych przez Bogusława Milerskiego i Macieja Karwowskiego (2016) w ostatnim czasie wynika, że można zidentyfikować więcej niż dwa rodzaje racjonalności występujące w procesie kształcenia (autorzy przyjmują tetragonalną koncepcję racjonalności), jednak w podejmowanych rozważaniach wychodzę od dwóch głównych rodzajów racjonalności, które tworzą podbudowę teoretyczną do istnienia innych jej rodzajów.

Zgodnie z podejściem Kwaśnicy (2007: 9-14) każde działanie edukacyjne, bez względu na założony cel edukacji, sprzyja rozwojowi jednej z dwóch struktur doświadczenia. Doświadczenie stanowi element strukturalny racjonalności. 
W związku z powyższym, podmiot inicjujący działanie edukacyjne musi wybrać, za jakim typem racjonalności się opowiedzieć. Nie zawsze jednak są to wybory uświadomione (ze względu na brak wiedzy podmiotu na temat alternatyw, przed jakimi staje). Każde zachowanie nauczyciela dostarcza uczniowi pewnych wzorców i sposobów postrzegania, rozumienia rzeczywistości. To, w jaki sposób uczeń zinterpretuje konkretne zachowanie, zależy od jednej z dwóch perspektyw doświadczania świata; instrumentalnej lub emancypacyjnej.

Ze względu na obszar moich zainteresowań badawczych chciałabym się w szczególności skupić na racjonalności emancypacyjnej, której głównym wyznacznikiem jest interakcja. Najbardziej interesująca wydaje się interakcja komunikacyjna nauczycieli akademickich i studentów, rozpatrywana pod względem rodzajów podejmowanych działań i sposobów komunikacji.

Działanie komunikacyjne jest sposobem doświadczania świata za pomocą interakcji. Należy ono do racjonalności emancypacyjnej, zwanej również komunikacyjną. Za Habermasem można wyróżnić dwie dziedziny życia: pracę i interakcję. Interakcja jest to działanie oparte na komunikacji, w którym dominującą perspektywą interpretacyjną jest logika działania komunikacyjnego. Wskutek tego działania kształtuje się racjonalność emancypacyjna. Drugą wyodrębnioną dziedzinę życia stanowi praca, która jest działaniem celowo-racjonalnym; instrumentalnym lub strategicznym. Oznacza to, że osoba dochodzi do zrozumienia swojej sytuacji $\mathrm{w}$ perspektywie interpretacyjnej działania instrumentalnego, przez co kształtuje się racjonalność adaptacyjna (por. Habermas, 2002). Pierwsze działanie, komunikacyjne, jest aktywnością skierowaną na ludzi lub siebie za pośrednictwem symboli. Przebiega ono zgodnie $\mathrm{z}$ obowiązującymi normami, jedynym warunkiem jest wzajemne uznanie zachowań przez dwa podmioty uczestniczące $w$ interakcji (Habermas, 2002, 355). Drugi typ, celowo-racjonalny, opiera się na działaniu człowieka, na świat przedmiotów w celu ich opanowania.

Zatem nie jest możliwe poznanie świata bez kulturowego narzędzia - języka. Obiekty świata stają się naszym światem dopiero w momencie, w którym napotkają na język. Dzięki niemu rozumiemy świat i dostrzegamy jego obiekty. To właśnie za pośrednictwem języka powstaje racjonalność. Warto zmienić horyzont postrzegania języka, którego funkcja jest często umniejszana i kojarzona jedynie z perspektywy komunikacji. Funkcja komunikacyjna jest tylko jedną z funkcji, jakie pełni język (por. Kwaśnica, 2007).

Funkcje języka:

- poznawczo-symboliczna, język jako narzędzie myślenia, nazywania;

- komunikacyjna, język jako środek porozumiewania się (Kwaśnica, 2007, $33-40)$. 
Od celów i okoliczności zależy sposób działania, a przez to doświadczania świata. Tak samo od celów i okoliczności zależy rodzaj podjętej interakcji nauczyciela, czyli jego sposób komunikacji.

Podążając za myślą R. Kwaśnicy (2007), który w publikacji Dwie racjonalności. Od filozofii sensu, ku pedagogice ogólnej opisał filozofię racjonalności, w której to społeczeństwo podpowiada możliwe sposoby życia w świecie i rozumienia świata, możemy wynieść, że poprzez system preferencji i utrudnień składających się na ramy życia społecznego społeczeństwo wywiera wpływ na jednostkę. Nakłaniając tym samym do myślenia zgodnie z logiką działania instrumentalnego lub komunikacyjnego. Co wskazuje na to, że narzędzie, jakim posługuje się nauczyciel na zajęciach, jest kulturowo i społecznie uwarunkowane, przez co wszelkie odstępstwa, indywidualność sposobu komunikacji nauczyciela nie są wskazane, a nawet są zabronione. Ma to swoje uzasadnienie, jednak niewątpliwie prowadzi do ograniczenia autonomii nauczyciela i z góry przesądza o wyborze prowadzenia procesu kształcenia zgodnie z założeniami racjonalności adaptacyjnej. Przykładem mogą być zajęcia, które byłyby prowadzone „językiem współczesnej młodzieży” młodej generacji, który „cechuje silne osadzenie w nurcie potocznych zachowań komunikacyjnych, anglizowania wymowy (...)" (Miodek, 2012) być może prowadzenie zajęć $\mathrm{z}$ wykorzystaniem tego języka spotkałoby się $\mathrm{z}$ wyższym stopniem zrozumiałości przez studentów, a co za tym idzie, zwiększeniem poziomu motywacji do przedmiotu.

Wobec tego pojawia się pytanie, czy możliwe jest zupełne przygotowanie nauczyciela w zakresie kompetencji komunikacyjnych, a jeśli tak, to jakie kompetencje będą się w nie wpisywać. Czy obecny nurt kształcenia akademickiego zdominowały kompetencje wpisujące się w racjonalność adaptacyjną, cze emancypacyjną? Obecnie „kształcenie rozumiane jest jako wyposażanie kandydatów na nauczycieli w pełne kwalifikacje zawodowe, dokształcanie - jako uzupełnianie tych kwalifikacji prowadzące do pełnego przygotowania zawodowego, a doskonalenie - jako dostarczanie nauczycielom takiej wiedzy i takich umiejętności, które pozwalają wzbogacić pełne kwalifikacje zawodowe i wykroczyć poza nie" (Kwaśnica, 1994: 8). Zgodnie z powyższym zakłada się, że możliwe jest pełne przygotowanie nauczyciela do pełnionego zawodu, a co za tym idzie, istnieje pewien wzorzec, który pozwala określić stopień posiadanych kompetencji zawodowych nauczyciela.

O pełnym przygotowaniu do zawodu można mówić jedynie w przypadku zawodów opierających się na kompetencjach technicznych, które są powtarzalne i przewidywalne, w przeciwieństwie do kompetencji koniecznych w zawodzie nauczyciela. Ma to swoje uzasadnienie w swoistości zawodu, który opiera się na ciągłym działaniu i zmierzaniu się z sytuacjami nowymi, na których rozwiązanie 
nauczyciel pracuje sam według własnej wiedzy, intuicji, doświadczenia, bez bazowania na gotowym schemacie. Ponadto komunikacyjny charakter zawodu nauczyciela opiera się na środkach bazujących na osobowości podmiotu, który je stosuje. Nauczyciel postrzegany jest przez ucznia w sposób całościowy jako osoba (niezależnie czy jest tego świadomy, czy też nie) i w sposób całościowy wywiera wpływ na ucznia (Kwaśnica, 1994: 8-15). Nie można nie wspomnieć, że działanie komunikacyjne opiera się nie tylko na przekazach werbalnych, ale również na przekazach niewerbalnych: gestach, postawie, mimice i tylko postrzegane w sposób holistyczny, może być właściwie wykorzystywane.

Rozważania powyższe skupiały się głównie na samym akcie komunikacji, kompetencji komunikacyjnej, warto wobec tego przyjrzeć się bliżej, czym są kompetencje. Zdaniem Czerepaniak-Walczak (1997: 97-99) kompetencje to „szczególna właściwość wyrażająca się w demonstrowaniu na wyznaczonym przez społeczne standardy poziomie, umiejętności adekwatnego zachowania się". Pojęcie to używane jest w dwóch znaczeniach; w odniesieniu do posiadanych kwalifikacji i w drugim znaczeniu, jako zakresie uprawnień (por. Strykowski, 2005). W powyższym artykule pojęcie to wykorzystywane jest w znaczeniu pierwszym, jako kwalifikacja konieczna do pełnienia zawodu nauczyciela.

Występuje kilka podziałów kompetencji zawodowych nauczyciela, jednym z nich jest podział według Stanisława Dylaka, zgodnie z którym można wyróżnić; kompetencje bazowe, konieczne, pożądane (za Strykowski, 2005: 18). Wśród kompetencji uznanych za podstawowe na pierwszym etapie znajduje się komunikacja z uczniami, studentami, podopiecznymi; należy do kompetencji bazowych. „Kompetencje komunikacyjne - to wiedza na temat procesu komunikowania, a także umiejętność efektywnego nadawania i odbierania komunikatów" (Strykowski, 2005: 23). Poprzez komunikację nauczyciel określa nie tylko stosunek do wiedzy, ucznia, ale również charakter relacji, jaką tworzy. Prowadzi to do wniosku, że kompetencje komunikacyjne należą do kompetencji kluczowych w zawodzie nauczyciela.

Każdy nauczyciel, wykładowca jest dydaktykiem, ale co sprawia, że jest postrzegany jako dobry lub zły dydaktyk? Wciąż bez odpowiedzi wydaje się pozostawać pytanie: dlaczego studenci wolą słuchać jednych nauczycieli bardziej od innych? Czyżby decydujące znaczenie miał tu preferowany rodzaj racjonalności?

Aby nie pozostawiać bez odpowiedzi powyższych pytań, posłużę się myślą R. Kwaśnicy, która wydaje się być podsumowaniem podjętych rozważań. Miarą racjonalności komunikacyjnej nie jest zbieżność celów i skutków, ale zbieżność formy dyskursu $\mathrm{z}$ warunkami określającymi sytuację idealnej rozmowy. W toku komunikacji ustala się wspólne rozumienie obszarów rzeczywistości, przez co uczest- 
nictwo studentów w tych obszarach świata staje się tym pełniejsze, im pełniejszy jest ich udział w ustalaniu się ich rozumienia (Kwaśnica, 2007). Kryteria oceniające racjonalność działania komunikacyjnego, można odnaleźć za J. Habermasem (2002) wewnątrz samego działania. J. Habermas (por. Kwaśnica, 2007: 67-68) wywodzi je ze struktury języka, będącej formą życia społecznego.

\section{Literatura}

Bańko M. (red.). (2006). Wielki słownik ucznia, t. II. Warszawa.

Chmielowski B. (1984). Wychowanie w procesie kształcenia. „Chowanna” z. 4.

Czerepaniak-Walczak M. (1997). Aspekty i źródła profesjonalnej refleksji nauczyciela. Toruń.

Habermas J. (2002). Teoria działania komunikacyjnego T. I i T. II. Warszawa.

Hydzik B. (1993). Sytuacje dydaktyczne i ich wpływ na aktywizacje uczniów w procesie nauczania-uczenia się. "Studia Pedagogiczne” z. 22.

Klus-Stańska D. (2018). Paradygmaty dydaktyki. Myśleć teoria o praktyce. Warszawa.

Kuligowska K. (1984). Doskonalenie lekcji. Z problematyki optymalizacji kształcenia. Warszawa.

Kunowski S. (1981). Podstawy wspótczesnej pedagogiki. Łódź.

Kwaśnica R. (1994). Wprowadzenie do myślenia. O wspomaganiu nauczycieli w rozwoju. Wrocław.

Kwaśnica R. (2007). Dwie racjonalności. Od filozofii sensu ku pedagogice ogólnej. Wrocław.

Milerski B., Karwowski M. (2016). Racjonalność procesu kształcenia. Teoria i badanie. Kraków.

Miodek J. (2012). Wykład pt. Polszczyzna najmłodszych pokoleń. https://www.youtube.com/ watch?v=lLKIXsd6kh8, dostęp: 29.02.2017.

Niemierko B. (2007). Kształcenie szkolne. Podręcznik skutecznej dydaktyki. Warszawa.

Okoń W. (1984). Słownik pedagogiczny. Warszawa.

Palka S. (2011). Związki pedagogiki ogólnej z teoria i praktyka dydaktyczna [W:] M. Myszkowska-Litwa (red.). Pedagogika ogólna a teoria i praktyka dydaktyczna. Kraków.

Poplucz J. (1984). Optymalizacja działania pedagogicznego na lekcji. Warszawa.

Przetacznikowa M., Włodarski Z. (1979). Psychologia wychowawcza. Warszawa.

Sajdak A. (2013). Paradygmaty kształcenia studentów i wspierania rozwoju nauczycieli akademickich. Teoretyczne podstawy dydaktyki akademickiej. Kraków.

Strykowski W. (2005). Kompetencje współczesnego nauczyciela. „Neodidagmata” 27/28.

Tomaszewski T. (1976). Podstawowe formy organizacji i regulacji zachowania. [W:] T. Tomaszewski (red.). Psychologia. Warszawa. 